The purpose of this paper is to approach the concept of stigma in a dialogue with the lecture of Guimarães Rosa's story A Benfazeja. To achieve this objective, we conducted a review of the concept of stigma and the classification of stigmas proposed by Erving Goffman, and based on these data, we analyzed the characters of A Benfazeja and the way the story shows how bodies and identities of the characters are socially constructed. Incidentally we made some considerations about the position of the narrator in relation to the characters and the narratee and about some misunderstandings related to the theories of Erving Goffman and the socalled Chicago School.

Entradas para indexação

PALAVRAS-CHAVE: Guimarães Rosa. A Benfazeja. Erving Goffman. Estigma (Stigma).

KEYWORDS: Guimarães Rosa. A Benfazeja. Erving Goffman. Stigma.

LUGAR: Chicago [Escola de].

PESSOAS: Howard Becker, David Le Breton, Michel Foucault, Pierre Bourdieu

OBRAS: Primeiras estórias.

Texto integral

"A cor do carvão é um mistério; a gente pensa que ele é preto, ou branco."

Guimarães Rosa

\section{Considerações primeiras}

O objetivo do presente artigo é abordar a questão da estigmatização a partir de uma leitura do conto A Benfazeja, de Guimarães Rosa (1985). Para tanto, partimos do conceito e classificação dos estigmas feitos por Erving Goffman (1988), e procuramos identificar como eles se fazem presentes nas personagens do conto. 0 que fazemos, nas linhas que se seguem, não é propriamente uma crítica literária; é mais um estudo dos conceitos goffmanianos, em uma leitura muito livre do conto de Guimarães Rosa.

Temos certa afinidade com esse tipo de leitura, mais livre, que as obras de ficção possibilitam - uma leitura tão diferente das interpretações mais herméticas e pretensamente hegemônicas que são usualmente feitas 
dos textos jurídicos e religiosos - porquanto tais obras permitem explicar e exemplificar conceitos e teorizações sociológicas e possibilitam diálogos interessantes entre autores e obras a primeira vista distantes entre si.

Começaremos explicando, brevemente, que razões levaram à escolha de Goffman e Guimarães e, em seguida, abordaremos os estigmas e a construção social da identidade e do próprio corpo da personagem principal. Faremos uma breve digressão sobre o narrador e como ele se posiciona em defesa da protagonista do conto, e fazemos uma reflexão sucinta sobre Retrupé, outro personagem estigmatizado.

Antes de passar a essas reflexões, convém antecipar algo de mea culpa. Em alguns momentos, poderemos estar esclarecendo conceitos um tanto óbvios, mas que entendemos necessários para o desenvolvimento do trabalho. Por outro lado, ao longo do artigo, poderemos negligenciar outras leituras e estudos sobre Guimarães Rosa ${ }^{1}$, uma falha que pretendemos sanar em trabalhos futuros, até porque esta certamente não é a última leitura que pretendemos fazer da obra de Guimarães.

\section{Por que Erving Goffman e Guimarães Rosa?}

Quando falamos em Erving Goffman, ninguém parece disposto a questionar sua contribuição ou a dos assim chamados interacionistas simbólicos $^{2}$ para as ciências humanas e sociais; a Escola de Chicago ${ }^{3}$ é, por vezes, referida em vários campos com uma boa dose de reverencialismo. Paradoxalmente, se o reconhecimento de sua importância é um lugar comum e é possível encontrar ressonâncias da obra de Goffman em autores relevantes, como Bourdieu 4 e Foucault ${ }^{5}$, não são muitos os que parecem dispostos a se aprofundar e a desenvolver as ideias da referida Escola. Ao menos no Brasil, poucos trabalhos recentes parecem ir além de uma citação ou uma nota de pé de página, referindo e reverenciando a Goffman quando se fala em estigma ou a Howard Becker quando se trata da temática dos outsiders ou do labeling theory.

Acreditamos que esse cenário paradoxal pode estar relacionado às acusações feitas ao interacionismo, como por exemplo, o foco excessivo nos indivíduos e suas relações, deixando de abordar o aspecto macrossociológico, e, diretamente relacionado a isso, a existência de estudos sobre relações de desigualdade, mas sem uma proposta propriamente emancipatória.

Essas acusações não nos parecem inteiramente procedentes, e, embora esse não seja o trabalho mais adequado para discutir isso, estamos 
convencidos de que é possível desenvolver e estabelecer diálogos a partir dos aspectos críticos presentes nas obras dos sociólogos provenientes de Chicago, e é precisamente aqui que Goffman nos é útil, na reflexão sobre o conto A Benfazeja, avaliando como Guimarães Rosa constrói uma personagem desacreditada cuja trajetória é marcada pela estigmatização.

Se a escolha de Goffman precisa ser explicada em virtude da nossa visão de seus escritos e dos trabalhos dos demais chicagoenses destoar do que geralmente se diz sobre eles, a escolha de Guimarães é mais facilmente compreensível, dada a relevância de sua obra. 0 esclarecimento que talvez precisasse ser feito, sobre o porque de tentarmos intermediar um diálogo entre Guimarães e Goffman, é o que está no próprio corpo do artigo como um todo. Cabe uma nota, entretanto, sobre a escolha do conto:

\footnotetext{
"A benfazeja" é o décimo sétimo conto de Primeiras Estórias. Foi publicado originalmente no jornal 0 Globo, em 05 de agosto de 1961, e reunido, posteriormente, às outras vinte narrativas que compõem "o amarelinho" (...).

Este conto apresenta, em onze páginas, a trajetória da Mula-Marmela, uma mulher detestada pela comunidade onde vive. Demasiadamente feia, ela perambula pelo lugarejo guiando seu enteado, o cego Retrupé. Condenada pelo assassinato do marido, o Mumbungo, e acusada de cegar e estrangular o enteado até a morte, a Mula-Marmela é expulsa do lugar sem direito a julgamento justo e sem chance de defesa. (RoLIM, 2010, p. 68, grifos do original)
}

A síntese de Marina Ambrozio Galindo Rolim ajuda a explicar a escolha, alguém detestada como Mula Marmela, marcada pelo crime e pela feiura, expulsa da comunidade, certamente fornece grandes possibilidades de reflexão em relação aos conceitos goffmanianos.

\section{As marcas e a construção social no corpo da benfazeja}

O cenário que a leitura nos permite (re)construir é o de uma pequena comunidade, um povoado desses onde todos podem ter conhecimento do indivíduo estigmatizado. ${ }^{6}$ A personagem principal do conto que estamos interpretando é uma mulher, estigmatizada e, como tal, 
desacreditada. Dentre as marcas que carrega, estão o crime, a velhice e a feiura:

Sei que não atentaram na mulher; nem fosse possível. Vive-se perto demais, num lugarejo, às sombras frouxas, a gente se afaz ao devagar das pessoas. A gente não revê os que não valem a pena. Acham ainda que não valia a pena? Se, pois, se. No que nem pensaram; e não se indagou, a muita coisa. Para quê? A mulher - malandraja, a malacafar, suja de si, misericordiada, tão em velha e feia, feita tonta, no crime não arrependida - e guia de um cego. Vocês todos nunca suspeitaram que ela pudesse arcar-se no mais fechado extremo, nos domínios do demasiado?

Soubessem-lhe ao menos o nome. Não; pergunto, e ninguém o inteira. Chamavam-na de a "Mula-Marmela", somente, a abominada. A que tinha dores nas cadeiras: andava meio se agachando; com os joelhos para diante. Vivesse embrenhada, mesmo quando ao claro, na rua. Qualquer ponto em que passasse, parecia apertado. Viam-lhe vocês a mesmez furibunda de magra, de esticado esqueleto, e o se sumir de sanguexuga, fugidos os olhos, lobunos cabelos, a cara -; as sombras carecem de qualquer conta ou relevo. Sabe-se assustava-os seu ser: as fauces de jejuadora, os modos, contidos, de ensalmeira? Às vezes,tinha o queixo trêmulo. Apanhem-lhe o andar em ponta, em sestro de égua solitária; e a selvagem compostura. Seja-se exato. (GUIMARÃES ROSA, 1985, p. 113, grifos do original)

Mula-Marmela, não tem nome além do que apelido que lhe deram. Seria tal apelido mais apropriado para denominar a mulher, com todas as marcas que possui? Aqui temos o mote para refletir sobre a questão dos estigmas. Segundo Goffman, o termo estigma foi cunhado na Grécia antiga para se referir a sinais corporais que expunham algo de extraordinário ou ruim sobre o status moral de quem os possuía. Como exemplo, ele menciona as cicatrizes que marcavam o escravo, o criminoso ou o traidor. Em quaisquer dos casos, "uma pessoa marcada, ritualmente poluída, que devia ser evitada; especialmente em lugares públicos” (GOFFMAN, 1988, p. 11).

Ainda é Goffman quem nos diz que na atualidade o estigma "é amplamente usado de maneira um tanto semelhante ao sentido literal original, porém é mais aplicado à própria desgraça do que à sua evidência corporal. Além disso, houve alterações nos tipos de desgraças que causam preocupação" (1988, p. 11). Os estigmas fazem, portanto, referência a atributos amplamente depreciativos. Goffman identifica pelo menos três grandes categorias de estigma: 
Podem-se mencionar três tipos de estigma nitidamente diferentes. Em primeiro lugar, há as abominações do corpo - as várias deformidades físicas. Em segundo, as culpas de caráter individual, percebidas como vontade fraca, paixões tirânicas ou não naturais, crenças falsas e rígidas, desonestidade, sendo essas inferidas a partir de relatos conhecidos de, por exemplo, distúrbio mental, prisão, vício, alcoolismo, homossexualismo, desemprego, tentativas de suicídio e comportamento político radical. Finalmente, há os estigmas tribais de raça, nação e religião, que podem ser transmitidos através de linhagem e contaminar por igual todos os membros de uma família. (GoFFMAN, 1988, p. 14)

No caso de Mula-Marmela, vemos que ela possui pelo menos uma culpa de caráter individual, um crime do qual não se arrepende. É interessante atentar para como o narrador apresenta, de forma sutil, o ilícito que ela cometeu, algo que ele irá retomar e justificar em outras passagens. E convém acrescentar que, embora Goffman, na passagem que citamos acima, se refira ao relato conhecido de prisão, a simples acusação do desvio pode ser suficiente para estigmatizar.

Goffman vai deixar isso claro em relação à loucura (cf. 2010, passim, esp. p. 117-118), mas esse aspecto do desvio, como uma decorrência da acusação ou imputação que é feita ao indivíduo, vai ficar especialmente claro em Howard Becker, quando ele fala na situação do falsamente acusado, ou seja, quando a pessoa "é vista pelos outros como se tivesse cometido uma ação imprópria, embora de fato não o tenha feito." (2008, p. 32). A estigmatização não prescinde, portanto, da existência do crime, mas da sua acusação:

0 ponto é que a resposta das outras pessoas deve ser vista como problemática. 0 simples fato de uma pessoa ter cometido uma infração a uma regra não significa que outros reagirão como se isso tivesse acontecido. (Inversamente, o simples fato de ela não ter violado uma regra não significa que não possa ser tratada, em algumas circunstâncias, como se o tivesse feito.) (BECKER, 2008, p. 24)

A próxima categoria de estigmas presentes em Mula-Marmela são as abominações do corpo, e aqui temos uma questão delicada em relação à obra de Goffman: a expressão em questão pode ser considerada preconceituosa? Mesmo que não seja, em diversas outras passagens, a versão em língua portuguesa de Estigma se refere, por exemplo, às pessoas com deficiência, com termos que atualmente podem ser considerados discriminatórios, tais como deformado, inválido, defeituoso, aleijado etc. ${ }^{7}$ 
Parte do problema decorre da tradução; expressões como crippled e lame person ( $c f$. GOFFMAN, 1990, p. 15 e 20) são traduzidas simplesmente como aleijado ( $c f$. GOFFMAN, 1988, p. 15 e 19). Mas a verdade é que não parece haver, em Stigma, uma preocupação com termos politicamente corretos, o que pode ser uma decorrência da época em que foi escrito ${ }^{8}$, ou, talvez, porque o objetivo declarado de Goffman era aclarar questões referentes ao estigma, separando-o de fatos vizinhos e esclarecendo sua relação com o desvio, e assim seria compreensível o uso dos referidos vocábulos, porquanto nada mais são do que os termos que a sociedade emprega(va) para denominar os estigmatizados.

Lendo a obra hoje, portanto, podemos interpretar a eventual rudeza das palavras de Goffman como uma exposição da rudeza da própria sociedade ao estabelecer os estigmas e suas consequências ${ }^{9}$. Essa seria, de certa forma, uma atualização hermenêutica da obra de Goffman. Dito isso, no que concerne às abominações do corpo, convém perceber que Mula-Marmela era velha, magra, feia, feita tonta e andava meio se agachando com seus joelhos para diante. Em suma, tinha uma compostura selvagem.

Percebemos que a protagonista apresenta, portanto, uma série de estigmas, e isso porque desconsideramos os termos típicos da escrita rosiana, os neologismos, e o recurso a palavras do português arcaico e da fala popular. Termos como malandraja, malacafar e furibunda - dentre outros - certamente não são termos amplamente empregados, mas mesmo que seu significado não seja facilmente acessível, sua relação com o co-texto e a própria forma como soam, nos dão a ideia de outros atributos depreciativos.

Tanto em nossa leitura de Goffman como na de Guimarães, identificamos indícios, motes para uma sociologia do corpo, para uma reflexão sobre o corpo enquanto local da identidade e fronteira entre o indivíduo e a sociedade. Se em Goffman isso fica claro no estigma enquanto construção social imputada ao indivíduo, em Guimarães os indícios podem ser mais sutis, mas eles aparecem, como, por exemplo, quando o narrador resolve defender a protagonista e sugerir que ela talvez não seja o que os outros pensam:

E nem desconfiaram, hem, de que poderiam estar em tudo e por tudo enganados? Não diziam, também, que ela ocultava dinheiro, rapinicado às tantas esmolas que o cego costumava arrecadar? Rica, outromodo, sim, pelo que do destino, o terrível. Nem fosse reles feiosa, isto vocês poderiam notar, se capazes de desencobrir-lhe as feições, de sob o sórdido desarrumo, do sarro e crasso; e desfixar-lhe os rugamentos, que não de idade, senão de crispa expressão. Lembrem-se bem, façam um esforço. Compesem-lhe as palavras parcas, os gestos, uns atos, e tereis 
que ela se desvendava antes ladina, atilada em exacerbo. (...) (GUIMARÃES RosA, 1985, p. 113, grifos do original)

O narrador nos leva a questionar se a feiura de Mula-Marmela era inerente à sua pessoa ou se era algo que lhe foi socialmente imposto. Começa a ficar claro como ele irá advogar em defesa da protagonista - e iremos abordar esse aspecto da narrativa posteriormente - , mas agora o que vai nos interessar especificamente é a construção social do seu corpo. Já vimos que os estigmas são marcas que o indivíduo possui, mas o seu desvalor e suas consequências para o indivíduo estigmatizado são estabelecidos pela sociedade. Queremos ampliar essa questão, abordando como o corpo do indivíduo, como um todo, pode ser socialmente construído:

A expressão corporal é socialmente modulável, mesmo sendo vivida de acordo com o estilo particular do indivíduo. Os outros contribuem para modular os contornos de seu universo e a dar ao corpo o relevo social que necessita, oferecem a possibilidade de construir-se inteiramente como ator do grupo de pertencimento. No interior de uma mesma comunidade social, todas as manifestações corporais do ator são virtualmente significantes aos olhos dos parceiros. Elas só têm sentido quando relacionadas ao conjunto de dados da simbologia própria do grupo social. Não há nada de natural no gesto ou na sensação. (LE BRETON, 2010, p. 9)

O corpo parece explicar-se a si mesmo, mas nada é mais enganoso. 0 corpo é socialmente construído, tanto nas suas ações sobre a cena coletiva quanto nas teorias que explicam seu funcionamento ou nas relações que mantém com o homem que encarna. A caracterização do corpo, longe de ser unanimidade nas sociedades humanas, revela-se surpreendentemente difícil e suscita várias questões epistemológicas. 0 corpo é uma falsa evidência, não é um dado inequívoco, mas o efeito de uma elaboração social e cultural. (LE BRETON, 2010, p. 26)

Aqui temos duas questões sobre as quais temos de refletir. Primeiro temos a interpretação das manifestações do indivíduo, e por mais que este indivíduo possa tentar exercer alguma influência na forma como seu corpo é visto pelos demais, ele nunca poderá ter controle absoluto de tais interpretações. Da mesma forma como os significados do estigma são socialmente atribuídos, o significado do corpo como um todo também é elaborado socialmente. 
Além disso, temos a questão da interiorização dos modelos sociais pelo indivíduo. Não queremos nos estender sobre como a mente é (re)formada socialmente e como ela, por sua sua vez (re)forma o corpo; basta compreender que isso pode ocorrer - e efetivamente ocorre dentro da sociedade. Aqui queremos nos referir a um processo análogo ao que Bourdieu ( $c f$. NOGUEIRA; CATANI, 1998; BoURDIEU, 1996) descrevia quando falava em como esquemas de comportamento são inscritos no corpo, mas, numa perspectiva mais - por assim dizer - interacionista, ou seja, em como um determinado indivíduo pode ser socialmente moldado nas suas interações com os demais.

Essa perspectiva também pode ser encontrada em diversas passagens da obra de Goffman (1988), ora de forma explícita, ora subjacente. Ele vai nos lembrar, por exemplo, como a pessoa constrói a imagem que tem de si próprio a partir do material com o qual as outras pessoas já construíram a sua identificação pessoal e social (p. 117), e como a sociedade imputa o estigma ao indivíduo e espera que ele aja como estigmatizado (p. 118-121), ou, resumindo, em suas próprias palavras: "a natureza de uma pessoa, tal como ela mesma e nós a imputamos, é gerada pela natureza de suas filiações grupais." (p. 124)

Queremos sugerir que o corpo de Mula-Marmela é condicionado pela percepção que os outros têm dela, sendo que, como nos revelou o narrador nas passagens anteriormente transcritas, ela não é necessariamente feia, são os outros que a veem feia, que constroem socialmente sua feiura. E ela, por sua vez, não tem como controlar as interpretações que os outros fazem dela. Mula-Marmela, além disso, pode incorporar a feiura que lhe é imputada, por exemplo, em suas expressões ou em seu andar, meio se agachando, com os joelhos projetados à frente. Falando com Goffman (1988, p. 41), diríamos que Mula-Marmela, a estigmatizada, aprende e incorpora o ponto de vista dos seus estigmatizadores.

\section{Uma palavra sobre o narrador}

Sugerimos, linhas acima, que o narrador em $A$ Benfazeja atua quase como se fosse o advogado da protagonista. As passagens que transcrevemos mostram como o conto é narrado em primeira pessoa e a forma interessante como Guimarães constrói o narrador ${ }^{10}$, pois ao mesmo tempo em que ele é alguém de dentro (insider) do povoado, que acompanha as interações entre os indivíduos e presta especial atenção na Benfazeja, isso faz com que ele paradoxalmente? - seja alguém de fora (outsider) ${ }^{11}$. Não se trata aqui de tomá-lo apenas como alguém de fora do povoado, o que ele efetivamente diz 
ser ( $c f$. GUIMARÃES RoSA, 1985, p. 115), mas de fora da sociedade e de seus valores ${ }^{12}$.

0 narrador não compactua com a opinião das demais personagens sobre a Benfazeja; em algumas passagens, ele atua como defensor dela, quase como se fosse seu advogado, minimizando seus desvios e criticando o juízo que as demais personagens fazem. 0 próprio título, aliás, já denuncia $a$ tese, o conto não se chama "Mula-Marmela", nem "A mulher malandraja" ou "A furibunda de magra": ele se chama "A Benfazeja", a que faz o bem, a caridosa.

Não iremos desenvolver a questão - aliás, interessantíssima - de como o narrador parece fracassar em sua defesa, empenhando-se arduamente em uma causa perdida. Queremos apenas chamar atenção para a forma como ele, depois de desconstruir a feiura que socialmente é imposta à protagonista, minimiza o crime que ela cometeu. A própria forma como o crime é introduzido é interessante, apenas uma vaga menção no primeiro parágrafo que transcrevemos acima: "no crime não arrependida - e guia de um cego" (GUIMARÃES RoSA, 1985, p. 113), sem maiores esclarecimentos, e a sua tarefa de guia do cego desviando a nossa atenção do crime.

Adiante, quando o crime é efetivamente abordado, ele acaba assumindo um discurso de defesa em relação à Benfazeja:

(...) Seu antigo crime? Mas sempre escutei que o assassinado por ela era um hediondo, o cão de homem, calamidade horribilíssima, perigo e castigo para os habitantes deste lugar. Do que ouvi, a vocês mesmos, entendo que, por aquilo, todos lhe estariam em grande dívida, se bem que de tanto não tomando tento, nem essa gratidão externassem. Tudo se compensa. Por que, então, invocar, contra as mãos de alguém, as sombras de outroras coisas? (GUIMARÃES ROSA, 1985, p. 114)

Ele não se refere tão somente a um crime, mas a um antigo crime, e, na sequência, introduz um operador argumentativo adversativo, o mas, e justifica o acontecido com base no que sempre escutou ${ }^{13}$ - das próprias pessoas do povoado? Os que estigmatizavam a Benfazeja? - sobre o assassinado ser, ele próprio, um criminoso terrível. E arremata dizendo que o povoado devia ser grato à protagonista ou, ao menos, que deixassem o antigo crime no passado, que o esquecessem. Em outra passagem, ele torna a abordar o crime, relativizando-o com a questão do tempo: 
(...) 0 cego Retrupé era filho do finado marido dela, o "Mumbungo", que a Mula-Marmela assassinara.

Vocês sabem, o que foi[14] há tantos anos. Esse Mumbungo era célebrecruel e iníquo, muito criminoso, homem de gostar do sabor de sangue, monstro de perversias. Esse nunca perdoou, emprestava ao diabo a alma dos outros. Matava, afligia, matava. Dizem que esfaqueava rasgado, só pelo ancho de ver a vítima caretear. Será a sua verdade? Nos tempos, e por causa dele, todos estremeciam, sem pausa de remédio. Diziam-no maltratado do miolo. Era o punir de Deus, o avultado demo - o "cão". E, no entanto, com a mulher, davam-se bem, amavam-se. Como? 0 amor é a vaga, indecisa palavra. Mas, eu, indaguei. Sou de fora. O Mumbungo queria à sua mulher, a Mula-Marmela e, contudo, incertamente, ela o amedrontava. Do temor que não se sabe. Talvez pressentisse que só ela seria capaz de destruí-lo, de cortar, com um ato de "não", sua existência doidamente celerada. Talvez adivinhasse que em suas mãos, dela, estivesse já decretado e pronto o seu fim. Queria-lhe, e temia-a - de um temor igual ao que agora incessante sente o cego Retrupé. Soubessem, porém, nem de nada. A gente é portador. (GUIMARÃES RoSA, 1985, p. 115, grifamos)

O narrador aprofunda a questão da personalidade do assassinado, sugerindo que seu assassinato era inevitável, era o destino da protagonista acabar com a vida e as maldades de seu companheiro, não seria possível exigir-lhe conduta diversa. Isso, entretanto, nos deixa com pelo menos duas questões para reflexão; a primeira é, como o narrador, que se diz de fora, percebe isso e os de dentro não? A segunda é, se ela prestou um favor à comunidade e se não era possível exigir que ela agisse de outra forma, como, então, se justifica que a Benfazeja continue estigmatizada? Desenvolveremos a reflexão sobre essas questões na próxima seção, ainda dando atenção ao papel do narrador, e refletindo sobre como o carrasco pode partilhar o descrédito do criminoso.

\section{0 carrasco (e o) criminoso}

0 narrador prossegue na defesa da Benfazeja. Talvez o fato de se ver como alguém de fora explique sua curiosidade em relação à protagonista. Podemos imaginar a sua chegada ao povoado; enquanto apreendia os valores a padrões locais, talvez lhe fosse mais fácil não ser seduzido pelo lugar comum, pelo estereótipo da Mula-Marmela. Isso, evidentemente, são divagações de leitor. De qualquer forma, elas explicariam porque ele presta tanta atenção nela, se inteirando de sua história, a ponto de conhecê-la em detalhes: 
O pai, o Mumbungo, se vivia bem com a mulher, a Mula-Marmela, e se ela precisava dele, como os pobres precisam uns dos outros, por que, então, o matou? Vocês nunca pensaram nisso, e culparam-na. Por que hão de ser tão infundados e poltrões, sem espécie de perceber e reconhecer? Mas, quando ela matou o marido, sem que se saiba a clara e externa razão, todos aqui respiraram, e bendisseram a Deus. Agora, a gente podia viver o sossego, o mal se vazara, tão felizmente de repente. O Mumbungo; esse, foi o que tivera de se revoltar a um outro lugar, foi como alma que caiu no inferno. Mas não a recompensaram, a ela, a MulaMarmela ao contrário: deixaram-na no escárnio de apontada à amargura, e na muda miséria, pois que eis. Matou o marido, e, depois, própria temeu, forte demais, o pavor que se lhe refluía, caída, dado ataque, quase fria de assombro de estupefazimento, com o cachorro uivar. E ela, então, não riu. Vocês, os que não a ouviram não rir, nem suportam se lembrar direito do delirido daquela risada. (GUIMARÃES RosA, 1985, p. 116)

O narrador conhece a história da protagonista, e conhece tão bem que se sente seguro em assumir um ar de reprovação em relação à comunidade. Vemos, mais uma vez, o narrador esclarecendo e justificando a morte de Mumbungo, agora acusando o narratário, no caso os demais indivíduos do povoado - "tão infundados e poltrões" - por estigmatizarem injustamente a Benfazeja. 0 que justificaria essa estigmatização? Eles veem Mula-Marmela e não a Benfazeja, mas por que eles não reconhecem, espontaneamente, as virtudes da protagonista? Por que, para eles, é mais fácil estigmatizar?

Já divagamos sobre o porquê de o narrador não se apegar ao senso comum do povoado; sendo de fora, ele estaria mais livre do senso comum local. Mas isso ainda não explica por que os locais estigmatizam aquela que lhes livrou do criminoso, do célebre-cruel. A hipótese que achamos mais provável é que a benfazeja tenha compartilhado os estigmas do famigerado Mumbungo.

Sabemos que, hoje, o direito formalmente posto consagra o assim chamado princípio da personalidade ou intranscendência, pelo qual nenhuma pena passará da pessoa do condenado ${ }^{15}$, mas também sabemos que nem sempre foi assim; na vida social real, aliás, nem sempre é assim. Enquanto vivo, Mumbungo era temido pela comunidade, esse temor pode ter-se revestido em rejeição à sua companheira enquanto ele ainda era vivo ${ }^{16}$, e, quando ela o mata, ela própria se torna uma criminosa, pouco importando que o crime fosse inevitável ou que ele tenha trazido um bem para a comunidade. 
Se eu disser o que sei e pensam, vocês inquietos se desgostarão. Nem consintam, talvez, que eu explique, acabe. A mulher tinha de matar, tinha de cumprir por suas mãos o necessário bem de todos, só ela mesma poderia ser a executora - da obra altíssima, que todos nem ousavam conceber, mas que, em seus escondidos corações, imploravam. Só ela mesma, a Marmela, que viera ao mundo com a sina presa de amar aquele homem, e de ser amada dele; e, juntos, enviados. Por quê? Em volta de nós, o que há é a sombra mais fechada - coisas gerais. A MulaMarmela e o Mumbungo, no fio a fio de sua afeição, suspeitassem antecipadamente da sanção, e sentença? Temia-a, ele, sim, e o amor que tinha a ela colocava-o à mercê de sua justiça. A Marmela, pobre mulher, que sentia mais que todos, talvez, e, sem o saber, sentia por todos, pelos ameaçados e vexados, pelos que choravam os seus entes parentes, que o Mumbungo, mandatário de não sei que poderes, atroz sacrificara. Se só ela poderia matar o homem que era o seu, ela teria de matá-lo. Se não cumprisse assim - se se recusasse a satisfazer o que todos, a sós, a todos os instantes, suplicavam enormemente - ela enlouqueceria? A cor do carvão é um mistério; a gente pensa que ele é preto, ou branco. (GUIMARÃEs RoSA, 1985, p. 116-117)

Em sua defesa da Benfazeja, o narrador que anteriormente havia relembrado como todos do povoado respiraram, bendisseram a Deus quando Mumbungo foi morto, agora apresenta a protagonista como sendo apenas a cumpridora de sua tarefa, só ela poderia matá-lo e ela teria de fazê-lo, com isso satisfazendo a vontade de todos, que ainda assim a estigmatizam. Aqui lembramos da figura do carrasco, que, como nos lembra Foucault, partilhava da infâmia do criminoso:

Em sua confrontação com o condenado, o executor era um pouco como o campeão do rei. Campeão entretanto não condenável e condenado: a tradição dizia, parece, que quando as cartas do carrasco haviam sido lacradas, não eram postas na mesa, mas jogadas à terra. Conhecem-se todas as proibições que cercam esse "ofício muito necessário", mas "contrário à natureza". Apesar de o carrasco ser, em certo sentido, o gládio do rei, partilhava da infâmia do adversário. 0 poder soberano que o obrigava a matar, e que agia através dele, não estava presente nele: não se identificava com sua fúria. (FoUCAULT, 2010a, p. 52)

Apesar de Foucault estar se referindo a um contexto que não é igual ao que encontramos no conto, a analogia ao carrasco é sedutora porque nos lembra como podem existir tarefas que julgamos necessárias mas com as quais não pretendemos sujar as mãos, e podemos rejeitar quem as 
desempenha. Nós queremos vê-las realizadas, mas não nos reconhecemos na sua realização.

Refletindo sobre a questão do carrasco e do criminoso, fica evidente que não há uma lógica cartesiana nesse processo. Nem o carrasco nem o criminoso serão sempre odiados, nem, tampouco, Foucault diz isso. Sua obra nos leva a pensar sobre como é possível ter afinidade com certos criminosos (cf. FoucAUlT, 2010a, passim, esp. p. 64-65). Poderíamos ter afinidade com uma protagonista que fosse uma justiceira? Talvez. Mas como o povoado poderia ter afinidade com o Mumbungo? o célebre-cruel que matava, que gostava do sabor de sangue. $O$ monstro de perversias.

0 monstro. 0 narrador nos expõe Mumbungo como algo além de um indivíduo a ser corrigido, alguém que esfaqueava rasgado, só pelo ancho de ver a vítima caretear? Como diz o narrador, em passagem que já transcrevemos, ele era o "cão", o avultado demo. Mumbungo parece-nos o monstro sobre o qual escreve Foucault (cf. 2010a, passim e 2010b, passim, esp. p. 47), aquele que em sua existência é, não apenas uma violação das leis da sociedade, como também uma violação das leis da própria natureza.

Acreditamos que essa é a razão por que, no povoado, apenas o narrador outsider simpatiza com a protagonista. No conto de Guimarães, temos Mula-Marmela partilhando duplamente os atributos negativos de Mumbungo, ela é sua companheira e depois sua assassina; essa partilha a faz diferente. Essas são, também, marcas que conduzem à exclusão. ${ }^{17-18}$

E, se, ainda assim, é possível ao narrador defendê-la, é porque essa partilha de atributos não é algo que lhe é intrínseco, mas algo que lhe é atribuído socialmente. Parafraseando, é a gente que pensa que o carvão é preto, ou branco, e diz que ele é dessa forma, e atribui os valores e sanções sociais às marcas que o carvão apresenta.

\section{Retrupé, mais um estigmatizado}

Retrupé é mais um personagem intrigante; cego, filho do finado Mumbungo e enteado da Benfazeja, que se torna a sua curadora, a sua guia. Ele herdou o temor por Mula-Marmela e herdou, principalmente, a índole do pai. Retrupé é descrito, não como a pessoa com deficiência que reivindica reconhecimento, mas muito mais como um ser galtoniano que herda as más características de seu pai: 
O cego Retrupé é grande, forte. Surge, de lá, trazido pela Mula-Marmela; agora se conduz firme, não vacila. Dizem que bebe? Vejam vocês mesmos, porém, como essas petas escondem a coisa singular. Todos sabem que ele não bebia, nunca, porque a Mula-Marmela não deixava. Nem carecia de falar-lhe a paz da proibição: dava-lhe, apenas, um silêncio, terrível. E ele cumpria, tinha a marca da coleira. Curtia afogados desejos, indecifrava-os. Aspirava, à porta dos botequins, febril, o espírito das cachaças. Seguia, enfim, perfidiado e remisso, mal-agradecido, raivoso, os dentes do rato rangiam-no. Porque, ele mesmo, não sabendo que não havia de beber, o que não fosse - ah, se! - o sangue das pessoas. Porque sua sede e embriaguez eram fatais, medonhas outras, para lá do ponto. Seria ele, realmente, uma alma de Deus, hão certeza? Ah, nem sabem. Podia também ser de outra essência - a mandada, manchada, malfadada. Dizem- se, estórias. Assim mesmo no tredo, estado em que tateia, privo, malexistente, o que é, cabidamente, é o filho tal-pai-tal; o "cão", também, na prática verdade. (GUIMARÃES RoSA, 1985, p. 115-116)

Retomando a classificação proposta por Goffman, percebemos que Retrupé apresenta, portanto, a culpa de caráter individual, assim como seu pai apresentava, e a abominação do corpo, no caso, a cegueira ${ }^{19}$. Um aspecto interessante de Retrupé, que merece reflexão, é que ele foge daquele estereótipo - preconceituoso - estabelecido em relação à pessoa com deficiência: Retrupé não é o coitadinho, ele é o “cão", tal-pai-tal. Por um lado seria compreensível que o narrador frisasse esses aspectos de seu caráter com o intuito de valorizar a Benfazeja, mas ainda assim é interessante que, ao fazer isso, ele nos apresenta Retrupé como um ser ambivalente, ambíguo.

0 homem deficiente é um homem com estatuto intermediário, um homem do meio termo. 0 mal-estar que suscita vem igualmente da falta de clareza que cerca sua definição social. Ele nem é doente nem é saudável, nem morto, nem completamente vivo, nem fora da sociedade nem dentro dela, etc. Sua humanidade não é posta em questão e, no entanto, ele transgride a ideia habitual de humano. A ambivalência que a sociedade mantém a seu respeito é uma espécie de réplica à ambiguidade da situação, a seu caráter durável e intocável. (LE BRETON, 2010, p. 75-76)

E outra vez vejo que vêm, pela indiferente rua, e passam, em esmolambos, os dois, tão fora da vida exemplar de todos, dos que são os moradores deste sereno nosso lugar.[20] 0 cego Retrupé avança, fingindo-se de seguro, não dá à Mula-Marmela a ponta do bordão para segurar, ela o guia apenas com sua dianteira presença, ele segue-a pelo jeito, pelo se deslocar do ar - como em trasvôo se vão os pássaros; ou o que ele percebe à sua frente é a essência vivaz da mulher, sua sombra- 
da-alma, fareja-lhe o odor, o lobum? Notem que o cego Retrupé mantém sempre muito levantada a cabeça, por inexplicado orgulho: que ele provém de um reino de orgulho, sua maligna índole, o poder de mandar, que estarrece. E ele traz um chapéu chato, nem branco nem preto. Viram como esse chapéu lhe cai muitas vezes da cabeça, principalmente quando ele mais se exalta, gestilongado abarbarado e maldoso, reclamando com urgência suas esmolas do povo. Mas, notaram como é que a Mula-Marmela lhe apanha do chão o chapéu, e procura limpá-lo com seus dedos, antes de lho entregar, o chapéu que ele mesmo nunca tira, por não respeitar a ninguém? (GUIMARÃES ROSA, 1985, p. 117)

As passagens transcritas, de Le Breton e Guimarães Rosa, se articulam de forma interessante. Retrupé é o ser ambíguo que não se encontra nem fora da sociedade nem dentro dela: enquanto cego, ele depende da Benfazeja; enquanto pobre, depende das esmolas que recebe, mas ele não se porta como o coitado, mantém o orgulho, o poder de mandar, não respeita a ninguém. Vale ressaltar novamente que isso não significa, entretanto, que, em seu orgulho, Retrupé requeira dignidade; ele é descrito como alguém que herdou o temperamento e a índole ruim de seu pai:

O cego pedia suas esmolas rudemente. Xingava, arrogava, desensofrido, dando com o bordão nas portas das casas, no balcão das vendas. Respeitavam-no, mesmo por isso, jamais se viu que o desatendessem, ou censurassem ou ralhassem, repondo-o em seu nada. Piedade? Escrúpulo? Mais seria como se percebessem nele, de obscuro, um mando de alma, qualidade de poder. Chamava-se o Retrupé, sem adiante. Como a Mula-Marmela, os dois, ambos: uns pobres, de apelido. E vocês não vêem que, negando-lhes o de cristão, comunicavam, à rebelde indigência de um e outra, estranha eficácia de ser, à parte, já causada?

Ao Retrupé com seu encanzinar- se, blasfemífero, e prepotente esmolar, ninguém demorava para dar dinheiro, comida, o que ele quisesse, o pãopor-deus. - "Ele é um tranca!" - o cínico e canalha, vilão. Mas só, às vezes, alguém, depois e longe, se desabafava. 0 homem maligno, com cara de matador de gente. Sobre os trapos, trazia um facão, pendente. Estendia, imperioso, sua mão de tamanho. E gritava, com uma voz de cão, superlativa. Se alguém falasse, ou risse, ele parava, esperava o silêncio. Escutava muito, ao redor de si. Mas nunca ouvia tudo; não sabia nem podia. (GUIMARÃES ROSA, 1985, p. 114)

Assim, se desconsiderarmos aquela falta de clareza que cerca sua definição social a que se refere Le Breton, perceberemos que as pessoas com deficiência nada mais são do que pessoas, com qualidades e defeitos, como 
qualquer pessoa, o papel de deficiente, exigência da sociedade em relação ao estigmatizado ( $c f$. GONÇALVES, 2011). Isso fica evidente em Retrupé quando o narrador nos lembra que ele possui os mesmos desejos e necessidades de uma pessoa qualquer, e os vive dentro das limitações que a comunidade impõe à sua deficiência:

\begin{abstract}
Diziam que, em outro tempo, ao menos, entre eles teria havido alguma concubinagem. Cambonda? Vocês sabem que isso é falso; e como a gente gosta de aceitar essas simples, apaziguadoras suposições. Sabem que o cego Retrupé, canhim e discordioso, ela mesma o conduz, paciente, às mulheres, e espera-o cá fora, zela para que não o maltratem. Isto, porém, faz tempo. Hoje ele está envelhecido, virou em macilento, grisalho, as cãs assentam-lhe bem, quando o chapéu cai. Estes tempos, durante que deixamos de conhecê-los e averiguá-los. 0 cego Retrupé anda meio caído, amorviado, em escanifro e escanzelo. Parece que, ao mesmo passo, seu modo de medo da Mula Marmela muda e aumenta. Fraqueialhe também a fúria alastradora e áspera de viver: não exerce com o mesmo entono puxar pelo seu direito - o feroz direito de pedir. (GUIMARÃES RoSA, 1985, p. 119-120)
\end{abstract}

Mas, se é apenas uma pessoa, o que faz com que Retrupé seja a criatura lombrosiana, tal-pai-tal, descrita em outra passagem? De onde vem sua personalidade blasfemífera, prepotente, de homem maligno com cara de matador de gente? 0 narrador nos apresenta sua índole como sendo uma herança de Mumbungo, mas essa herança lhe é transferida geneticamente ou lhe é socialmente insculpida? Será que Retrupé é construído socialmente como o sucessor de direito de Mumbungo?

O narrador não nos oferece elementos suficientes para que possamos responder com certeza. Ele apenas descreve o que Retrupé é, e parece mais preocupado - como veremos - em justificar como ele se tornou cego. De qualquer forma, temos um mote interessante para mencionar rapidamente o labbeling approach, apresentado nos manuais, ora como um precursor da criminologia crítica, ora como uma de suas vertentes.

Em poucas palavras, a maior parte dos criminólogos parece compreender como labeling approach a perspectiva que vê o comportamento desviante como qualidade atribuída pelas agências de controle social, através da aplicação de regras e sanções, o que faz com que o criminoso seja, precisamente, o sujeito que é rotulado como criminoso. A associação do labeling approach aos sociólogos formados em Chicago é evidente; Becker, por exemplo, é referido como um dos precursores e Outsiders é uma das principais referências dessa abordagem ( $c f$. BARATTA, 2002, p. 89, ELBERT,1998, p. 90, SHECAIRA, 2008, p. 288). 
Estamos interessados, especialmente, em especular como a identidade de Retrupé pode ter se formado com base nas expectativas que o grupo social nutria em relação a ele, ou seja, na concepção de como a identidade do estigmatizado ou outsider pode apreender a carreira moral que lhe é imposta ( $c f$. GOFFMAN, 1988, passim, esp. p. 41-42, BECKER, 2008, p. 36 e ss). No dizer do criminólogo:

\begin{abstract}
Uma das maiores consequências do processo de desviação é o agente ser capturado pelo papel desviante. Este mergulho interativo será chamado pelos teóricos do labeling de role engulfment. No que concerne ao mergulho no papel desviado, podem-se destacar dois principais pontos de referência: como os outros definem o ator e como o ator se define. De maneira bastante cruel, pode ser dito que, à medida que o mergulho no papel desviado cresce, há uma tendência para que o autor do delito defina-se como os outros o definem. A personalidade do agente se referenciará no papel desviado, ainda que ele se defina como não desviado. (SHECAIRA, 2008, p. 288, grifos do original)
\end{abstract}

Claro que o agente tem a possibilidade de não ceder à assunção do papel desviado; não é como se a rotulação fosse algo irresistível e o indivíduo não tivesse outra escolha além de se conformar ao estigma. Aliás, é um equívoco o que comumente se faz: rotular obras, que muitas vezes têm pouco em comum, como sendo simplesmente interacionistas e achar que seus autores desconhecem a capacidade dos indivíduos de resistir à estigmatização ou de como as questões de classe se refletem no processo de labeling 21 .

De qualquer forma, se pensarmos que pode ter existido toda uma série de expectativas sobre a personalidade de Retrupé, relacionadas ao comportamento de Mumbungo, é possível supor que elas tenham inculcado nele as características que o fizeram um tranca, tal-pai-tal, ou que, pelo menos, contribuíram para tal. Essa possibilidade se torna ainda mais concreta quando lembramos que Retrupé não nasceu cego. A Benfazeja cega-o, justamente como forma de tentar domar-lhe a índole, e então se torna sua curadora:

Ela, não. Ela cuida dele, guia-o, trata-o - como a um mais infeliz, mais feroz, mais fraco. Desde que morreu o homem-marido, o Mumbungo, ela tomou conta deste. Passou a cuidá-lo, na reobriga, sem buscar sossego. Ela não tinha filhos. - "Ela nunca pariu..." - vocês culpam-na. Vocês, creio, gostariam de que ela também se fosse, desaparecesse no não, depois de ter assassinado o marido. Vocês odeiam-na, destarte. 
Mas, se ela também se tivesse matado, que seria de vocês, de nós, às muitas mãos do Retrupé, que ainda não estava cegado, nos tempos; e que seria tão pronto para ser sanguinaz e cruel-perverso quanto o pai e o que renega de Deus - da pele de Judas de tão desumana e tremenda estirpe, de apavor?

Seus os-olhos, do Retrupé, ainda eram sãos: para espelhar inevitável ódio, para cumprir o dardejar, e para o prazer de escolher as vítimas mais fáceis, mais frescas. Só aí, se deu que, em algum comum dia, o Retrupé cegou, de ambos aqueles olhos. Souberam vocês como foi? Procuraram achar? Sabem, contudo, que há leites e pós, de plantas, venenos que ocultamente retiram, retomam a visão, de olhos que não devem ver. Só com isso, sem precisão de mais, e já o Retrupé parava, um ser quase inócuo, um renunciado. E vocês, bons moradores do lugar, ficavam defendidos, a cobro de suas infrenes celeradezas. Talvez, ele não precisasse de danado morrer como o Mumbungo, seu pai. Talvez, me pergunto, o próprio Mumbungo descarecesse de ser morto, se acaso, por ponto, alguém pensasse antes nessas ervas cegadoras, ou soubesse já então de sua aplicação e efeito. Se assim, pois, haver-se-ia agora a Mula-Marmela guiando a dois, pelas ruas, e deles com terrível dever-deamor cuidando, como se fossem os filhos que ela queria, os que ela não pariu nem parirá, nunca - o dócil morto e o impedido cego; A pacto de tolher-lhes as ainda possíveis malícias, e dar-lhes, como em sua antiquíssima linguagem ela diz: gasalhado e emparo. (GUIMARÃES RoSA, 1985, p. 118)

A cegueira de Retrupé, portanto, é um remédio à índole que lhe é insculpida. Os olhos que não veem são o sinal corporal que evidenciam o seu status moral de pessoa marcada, ritualmente poluída, que deve ser evitada (cf. Goffman, 1988). Na narrativa, Retrupé é construído como um ser ambíguo, e a Benfazeja, que se viu obrigada a cegá-lo, passa a ser seus olhos, e, se pudesse - segundo o narrador - teria feito o mesmo com Mumbungo, poupando assim a sua vida. Mas, ainda assim, ela é odiada.

Ela cegou, precisava cegar, era sua função, assim como é sua função ser os olhos de Retrupé e sua curadora - inclusive, como vimos, levando-o aos prostíbulos - mas o povo não reconhece seus serviços, apenas a odeia, tanto que em suas simples e apaziguadoras suposições, diziam que entre Retrupé e Mula Marmela teria havido alguma concubinagem.

\section{A estigmatizada tem um último dever para com a comunidade...}


A cegueira, entretanto, não conserta Retrupé, e o narrador, que havia pensado a cegueira como um remédio também para Mumbungo, parece não se dar conta de que esse remédio teria sido insuficiente, ou pelo menos ele o foi em relação a Retrupé, ser ambíguo, que mantém sua índole ameaçadora:

\begin{abstract}
Conta-se-me que ele quis matá-la. Em hora em que seu medo se derramou maior, saber-se-á lá por quê? Tido que já se estava maltreito, quando adoeceu, mal, de febre acesa. Sentara-se à beira da rua, para arquejar. De repente, levantou-se, sem bordão, estorvinhado, gritou, bramou: exaltado como um cão que é acordado de repente. Sacou o facão, tacava-o, avançava às doidas, às mesmo cegas, tentando golpeá-la, em seu desatinado furor. E ela, erguida onde estava, permaneceu, não se moveu, não se intimidava? Olhava na direção do não. Se ele acertasse, poderia em carnes trucidá-la. Mas, aos poucos, acreditou que o facão não a encontraria nunca, sentiu-se desamparado demais e sozinho. Temeu, de todo em pé. 0 facão lhe caiu da mão. Seu medo não tinha olhos para encher.
\end{abstract}

Parece que gemeu e chorou: - "Mãe... Mamãe... Minha mãe!" esganiçado implorava, quando retombou sentado no chão, cessada a furibundância; e tremia estremecidamente, feito os capins dos pastos. Estava já no fino do funil, é de crer que. A Mula-Marmela, ela veio, se chegou, sem dizer nem o sussurrar. Apanhou-lhe o chapéu, limpou-o, tornou-o a pôr na cabeça dele, e trouxe também o facão, recolocou-o em sua cintura, na velha bainha. Ele, com o se apequenar de sofrer e tremer, semelhava um bicho do fundo da floresta. Diz-se que ela teria lágrimas nos olhos; que falou, soturna de ternuras terríveis - "Meu filho..." E olhou para uma banda, disse a alguma coisa mais, como se falando ao outro; soluçava, também, pelo Mumbungo, seu reconduzido marido, por sua parte, de seu ato. Disso, vocês não quererão saber, são em-diabas confusões, disso vocês não sabem. E, se, para quê? Se ninguém entende ninguém; e ninguém entenderá nada, jamais; esta é a prática verdade. (GUIMARÃEs ROSA, 1985, p. 120-121, grifos do original)

Retrupé permanece perigoso, ele não consegue matar a Benfazeja, não consegue atingi-la. Ela apenas espera o acesso passar e então o ajeita chapéu, facão - e, triste, talvez porque se dá conta do que deve ser feito também com Retrupé. Ele, por sua vez, tremeu estremecidamente, talvez porque estivesse arrependido do que tentou fazer à sua Benfazeja ou talvez porque já soubesse o que viria a seguir.

Retrupé é transgressor e ambíguo, não há lugar para ele na comunidade, como não havia para seu pai, e cabe à Benfazeja cumprir mais uma vez o papel de carrasco, que como vimos é outro ser que é socialmente construído de forma ambígua, já que o grupo social o entende necessário 
mas identifica nele a infâmia do criminoso. Com isso, vem uma última tarefa da Benfazeja para com Retrupé, um último dever para com a comunidade:

Sim, os dois, ficaram, até ao anoitecer, e pela noite entrada, naquela solidão próxima, numa beira de cerca. Alguém os acudiu? Diz-se que ele padecia uma dor terrivelmente, de demasiado castigo, e uma sufocação medonha de ar, conforme nem por uma esperança ainda nem não agoniava. Só estrebuchava. Não viram, na madrugada, quando ele lançou o último mau suspiro. Sim, mas o que vocês creem saber, isto, seriamente afirmam: que ela, a Mula-Marmela, no decorrer das trevas, foi quem esganou estranguladamente o pobre-diabo, que parou de se sofrer, pelos pescoços; no cujo, no corpo defunto, após, se viram marcas de suas unhas e dedos, craváveis. Só não a acusaram e prenderam, porque maior era o alívio de a ver partir, para nunca, daí que, silenciosa toda, como era sempre, no cemitério, acompanhou o cego Retrupé às consolações. Vocês, distantemente, ainda a odiavam?

E ela lá se indo, amargã, sem ter de se despedir de ninguém, tropeçante e cansada. Sem lhe oferecer ao menos qualquer espontânea esmola, vocês a viram partir: o que figurava a expedição do bode - seu expiar. Feia, furtiva, lupina, tão magra. Vocês, de seus decretantes corações, a expulsaram. Agora, não vão sair a procurar-lhe o corpo morto, para, contritos, enterrá-lo, em festa e pranto, em preito? Não será custoso achá-lo, por aí, caído, nem légua adiante. Ela ia para qualquer longe, ia longamente, ardente, a só e só, tinha finas pernas de andar, andar. É caso, o que agora direi. E, nunca se esqueçam, tomem na lembrança, narrem aos seus filhos, havidos ou vindouros, o que vocês viram com esses seus olhos terrivorosos, e não souberam impedir, nem compreender, nem agraciar. De como, quando ia a partir, ela avistou aquele um cachorro morto, abandonado e meio já podre, na ponta-darua, e pegou-o às costas, o foi levando: - se para livrar o logradouro e lugar de sua pestilência perigosa, se para piedade de dar-lhe cova em terra, se para com ele ter com quem ou quê se abraçar, na hora de sua grande morte solitária? Pensem, meditem nela, entanto. (GUIMARÃES RosA, 1985, p. 121-122)

Acabou sendo necessário sacrificar, também, Retrupé. A Benfazeja novamente cumpre o papel de carrasco, assim como em relação a Mumbungo; algo que apenas ela poderia fazer, satisfazendo a vontade de todos, e mais uma vez nenhuma gratidão lhe é dedicada: é mais um crime que ela comete. Assim como na morte de Mumbungo, ela não é acusada ou presa, o que sugere que a sua conduta é, ao menos em parte, aceita pela comunidade. É o mal necessário. Isso não significa, entretanto, que ela vá ficar impune, e é precisamente aqui que vem o último dever dela para com a comunidade, ela não é mais necessária e deve ir embora. Ela se autoexila ou é banida pela comunidade? 
Ela parte com o cachorro morto, já meio podre, às costas. 0 narrador não deixa claro - talvez ele mesmo esteja em dúvida - se ela enlouquece e por isso o leva, ou se está, conscientemente, realizando um último ato de higienização do local. Ambas as opções nos parecem corretas; a Benfazeja nos parece louca, não porque a loucura seja uma doença que lhe acomete, ao menos não no sentido de uma doença curável, mas porque a sociedade fê-la, também, louca.

Goffman nos mostra como a loucura é algo relativo; ela é condicionada socialmente, isso fica especialmente evidente em seu célebre trabalho sobre as instituições totais ( $c f$. 2010), trabalho que, como bem identificam Sílvio José Benelli e Abílio da Costa-Rosa (2003), ressoa em Foucault ${ }^{22}$. Não mencionamos isso para sugerir que Goffman seria uma referência não citada em Foucault, mas para registrar que, a depender dos interesses e pré-compreensões do intérprete, é possível encontrar as ressonâncias entre os dois autores, e falamos em ressonância não no sentido de uma intertextualidade manifesta, mas no sentido de um dialogismo mediado pelo intérprete.

No caso da loucura da Benfazeja, vai nos interessar o condicionamento da loucura às interações sociais que Goffman identifica e a explicação de Foucault sobre o louco ser o novo leproso ${ }^{23}$. Já vimos que o grupo não aceita a Benfazeja e a estigmatiza de diversas formas, de certa forma insculpindo nela as falhas e defeitos que o próprio grupo possui; uma vez que Mumbungo e Retrupé estão mortos, ela não tem mais utilidade para o grupo, sua exclusão deve ser, também, física.

Dissemos anteriormente que ela enlouquece, mas permanece consciente. Com isso queremos dizer que o ato dela, de se retirar com o cachorro nas costas, é consciente. Aos olhos da comunidade, há pouca ou nenhuma diferença entre a Benfazeja lupina e magra e o cachorro morto e meio já podre. Diríamos até que ambos são o mesmo ser indesejável, do qual a sociedade deve ser higienizada. Se o narrador, advogado da Benfazeja, nos parece em dúvida sobre as razões que a levaram a pegar o cachorro morto, e consequentemente sobre sua sanidade, a comunidade certamente reconheceria a loucura ${ }^{24}$.

E assim a Benfazeja, consciente de si e do que o grupo deseja para ela, realiza seu último dever, higienizando a comunidade de si mesma e do cachorro em decomposição. A presença do cachorro morto, aliás, é oportuna. Como na realização do senso comum de que o cão quando vai morrer afastase da casa, a Benfazeja, doente, louca, lupina, e ainda assim estranhamente consciente de seu último dever - enlouquecer e aceitar o banimento afasta-se da comunidade para morrer. 


\section{Considerações finais}

Nas linhas anteriores, exploramos o conceito de estigma, a partir da teorização de Erving Goffman e usando A Benfazeja como exemplo de como os atributos depreciativos são socialmente construídos. Começamos explicando que razões levaram à escolha de Guimarães Rosa e Goffman - e a assim chamada Escola de Chicago - para em seguida abordar o conceito de estigma, numa reflexão que conduziu à identificação de indícios de uma sociologia do corpo nas obras de Goffman e de Guimarães e à percepção de como a identidade e o corpo podem ser construídos socialmente.

Abordamos também a forma como o narrador - que em seu discurso transita entre o insider e o outsider, ora dizendo alguém de dentro do povoado, ora se posicionando como alguém de fora - defende a personagem principal. E se o narrador a defende, nós tentamos desnudar o que acontece com ela, como ela é socialmente construída. Ele, o narrador, expõe os estigmas da benfazeja de uma forma que nos permitiu sugerir que Mula-Marmela partilha dos estigmas de Mumbungo, seu companheiro já falecido, e de Retrupé, seu enteado. Sugerimos, também, que a protagonista incorpora o papel social que a comunidade estabelece para ela, e, posteriormente, que o mesmo pode ter ocorrido com Retrupé, cuja índole pode ter sido formada a partir das expectativas dos demais membros da comunidade.

Permeando essas reflexões, está a defesa que fizemos dos chicagoenses e a crítica que fizemos às leituras que consideramos apressadas e equivocadas de suas obras. Nesse sentido, esperamos que o presente artigo possa representar outra possibilidade de leitura de Guimarães Rosa e contribuir para uma maior reflexão sobre os conceitos goffmanianos, não porque eles consistam em um corpo teórico perfeito e acabado, mas porque eles permitem uma crítica e um desenvolvimento além das referências e reverências que normalmente lhe são feitas.

\section{NOTAS}

1 Tanto o esclarecimento de conceitos um tanto óbvios para outros estudiosos como a ausência de diálogo com outras leituras da obra de Guimarães se devem, também, ao fato de o autor do presente trabalho - jurista de formação - ainda estar se familiarizando com a obra de Guimarães.

2 Segundo Wilson Trajano Filho (2008), "Tudo indica que Goffman não apreciava ser associado a essa corrente de pensamento, não tanto pelas supostas divergências que teria com outros autores da mesma corrente, mas pelo fato dela ser um rótulo criado do exterior vazio de significado". 
3 Howard Saul Becker, considerado como um dos expoentes da referida escola, diz que "'Chicago' nunca foi a capela unificada do mito original, uma escola de pensamento unificada. Era, ao contrário, uma escola vigorosa e enérgica de atividade, um grupo de sociólogos que colaborou no trabalho quotidiano de fazer sociologia em uma universidade americana e fez isso muito bem. Mas nós não podemos fazer um salto inferencial, da colaboração pragmática para uma 'tradição', um corpo teórico coerente. O verdadeiro legado de Chicago é a mistura das coisas que caracterizam a escola de atividade em cada período: aberto, seja por opção ou necessidade, a uma variedade de formas de fazer sociologia, eclético porque as circunstâncias o impeliram a sê-lo." (1999, tradução livre)

4 Como lembra Felipe Tavares Paes Lopes, "se Bourdieu faz críticas veementes à teoria da ação de Goffman, parece também admirá-la profundamente. Prova disso é que, graças ao seu esforço editorial, a obra goffmaniana está mais bem traduzida em francês e mais abundantemente que a de qualquer outro sociólogo americano" (2009, p. 405)

5 Sobre as ressonâncias de Goffman em Foucault, cf. Benelul; CostA-Rosa (2003), citados na nota 22 logo abaixo.

6 "Para o indivíduo que leva uma existência típica de aldeia, quer numa pequena ou numa grande cidade, haverá poucas pessoas que só o conhecem de nome; aqueles que sabem coisas sobre ele talvez o conhecerão pessoalmente." (GofFMAN, 1988, p. 79)

7 Sobre a forma mais adequada de chamar as pessoas com deficiência, recomendamos o trabalho de Romeu Kazumi SASSAKI (2003).

8 Stigma foi publicado originalmente em 1963, nossa reimpressão em língua inglesa, entretanto, é de 1990.

9 "As atitudes que nós, normais, temos com uma pessoa com um estigma, e os atos que empreendemos em relação a ela são bem conhecidos na medida em que são as respostas que a ação social benevolente tenta suavizar e melhorar. Por definição, é claro, acreditamos que alguém com um estigma não seja completamente humano. Com base nisso, fazemos vários tipos de discriminações, através das quais efetivamente, e muitas vezes sem pensar, reduzimos suas chances de vida: Construímos uma teoria do estigma; uma ideologia para explicar a sua inferioridade e dar conta do perigo que ela representa, racionalizando algumas vezes uma animosidade baseada em outras diferenças, tais como as de classe social. Utilizamos termos específicos de estigma como aleijado, bastardo, retardado, em nosso discurso diário como fonte de metáfora e representação, de maneira característica, sem pensar no seu significado original." (GoFFMAN, 1988, p. 14-15, grifamos)

Essa é uma passagem interessante por pelo menos duas razões, a primeira é que nela já fica evidente como o estigma é uma construção sociocultural imposta a determinados indivíduos, de forma rude, pelos não-estigmatizados, e, além disso, ela mostra que Goffman não ignora que o estigma pode decorrer, por exemplo, de questões macro, como as relações entre as classes sociais.

10 Adotamos a distinção entre autor e narrador, conforme compreendida por Yves Reuter: "O escritor é um ser humano que existiu ou existe, em carne e osso, no nosso universo. Sua existência se situa no 'não-texto'. Ao seu lado, o narrador - aparente ou não - só existe no texto e mediante o texto, por intermédio de suas palavras. De qualquer modo, ele é um enunciador interno: aquele que, no texto, conta a história. O narrador é fundamentalmente 
constituído pelo conjunto de signos linguísticos que dão forma mais ou menos aparente àquele que narra a história." (REUTER, p. 19, grifos do original)

11 Embora conheça a história em detalhes, em algumas passagens o narrador se coloca como alguém de fora, o que, como veremos - e resgataremos posteriormente - acaba tendo uma finalidade argumentativa em relação ao narratário.

Aqui, recorremos novamente a Reuter (2002, p. 20, grifos do original): "O leitor é um ser humano que existiu, existe ou existirá, em carne e osso, no nosso universo. Sua existência situa-se no 'não-texto'. Por sua vez, o narratário - aparente ou não - só existe no texto e mediante o texto, por meio de suas palavras ou daquelas que o designam. Ele é quem, no texto, escuta ou lê a história. O narratário é fundamentalmente constituído pelo conjunto dos signos lingüísticos (o 'tu' e o 'você', por exemplo) que dão uma forma mais ou menos aparente a quem 'recebe' a história."

12 Rolim (2010, p. 68) também atenta para esse detalhe: "Por sua vez, o narrador, também anónimo, se destaca por possuir outra origem. Conforme declara, 'Sou de fora' (p. 179). Disso decorre que ele possua uma formação intelectual distinta das pessoas daquele lugar. Sendo assim, coloca-se diante da comunidade com um conhecimento de mundo capaz de contestar o pensamento provinciano vigente. Além disso, possui o distanciamento necessário para analisar os fatos sem ser corrompido pelos valores sentimentais e históricos autóctones."

13 Aqui voltamos à questão que havíamos mencionado anteriormente, sobre o narrador se posicionar como alguém de fora do povoado. Ao fazer isso, ele pode estar pressupondo uma informação que o narratário já conhece, se admitirmos que ele recorre a uma pressuposição - extrapolando um pouco, seria algo como: se eu que sou de fora sei, você que é do povoado deve saber - poderemos assumir que ele faz isso com uma finalidade argumentativa: convencer o narratário daquilo que ele supostamente já sabe.

Sabemos que a pressuposição é alvo de divergências, e estamos empregando o termo aqui sem maiores pretensões, além da reflexão sobre seu potencial argumentativo, pois como lembra Ingedore KOCH (2000, p. 73), "o uso retórico da pressuposição - justamente para anunciar aquilo que, aparentemente, funciona como pressuposto, é um recurso retórico de segundo nível, ou seja, faz parte da retórica ou pragmática aplicada, constituindo-se em manobra argumentativa de grande eficácia."

Ainda sobre pressuposição, numa perspectiva não tão diversa da que adotamos, $c f$. FAIRCLOUGH, 2001, p. 155-156.

14 Nessa passagem temos a questão que mencionamos anteriormente, do narrador fazendo uso da pressuposição como artifício argumentativo para convencer o narratário.

15 Um direito fundamental na Constituição de 1988: “art. 50 (...) XLV - nenhuma pena passará da pessoa do condenado, podendo a obrigação de reparar o dano e a decretação do perdimento de bens ser, nos termos da lei, estendidas aos sucessores e contra eles executadas, até o limite do valor do patrimônio transferido;" (BRASIL, 1988)

Com algumas variações, a intranscendência da pena é reconhecida em praticamente todos os ordenamentos positivados, Eugenio Raúl Zaffaroni diz que "Es este un principio que en el actual estadio de nuestra ciencia no requiere mayores consideraciones, aunque no haya sucedido lo mismo en otros horizontes de proyección de la ciencia jurídico penal. Nunca puede interpretarse una ley penal en el sentido de que la pena trasciende de la persona que es 
autora o participe del delito. La pena es una medida de carácter estrictamente personal, como que es una ingerencia resocializadora scbre el autor o partícipe. De allí que deba evitarse toda consecuencia de la pena que afecte a terceros." (1998, p. 315)

Adiante, porém, o mesmo jurista vai ponderar que "Desafortunadamente sabemos que en la realidad social la pena suele afectar a terceros, particularmente a los familiares del penado." (1998, p. 316)

16 "Deve ser levantado um último ponto no que se refere à informação social, ponto esse que se refere ao caráter informativo que tem o relacionamento 'com' alguém em nossa sociedade. Estar 'com' alguém é chegar em alguma ocasião social em sua companhia, caminhar com ele na rua, fazer parte de sua mesa em um restaurante, e assim por diante. A questão é que, em certas circunstâncias, a identidade social daqueles com quem o indivíduo está acompanhado pode ser usada como fonte de informação sobre a sua própria identidade social, supondo-se que ele é o que os outros são." (GOFFMAN, 1988, p. 57-58)

17 "Alguém que demonstra pertencer a uma categoria com atributos incomuns ou diferentes é pouco aceito pelo grupo social, que não consegue lidar com o diferente e, em situações extremas, o converte em uma pessoa má e perigosa, que deixa de ser vista como pessoa na sua totalidade, na sua capacidade de ação e transforma-se em um ser desprovido de potencialidades." (MELO, 1999, p 274)

18 “(...) a mulher fiel do paciente mental, a filha do ex-presidiário, o pai do aleijado, o amigo do cego, a família do carrasco, todos estão obrigados a compartilhar um pouco o descrédito do estigmatizado com o qual eles se relacionam." (GoFfMAN, 1988, p. 39)

19 Acreditamos que já esteja evidente que embora Goffman trate do estigma em sentido amplo, sua obra traz diversas referências e exemplos específicos de pessoas com deficiência, de forma que é perfeitamente possível abordar também a deficiência de Retrupé a partir da noção de estigma.

20 Cabe aqui mais uma observação sobre a o discurso do narrador, que em outro momento se disse de fora, agora ele faz questão de se dizer deste sereno nosso lugar, como se quisesse se aproximar do narratário a fim de obter sua adesão. Em seu discurso, o narrador oscila entre o dentro e o fora da comunidade de acordo com sua conveniência.

21 As críticas mais comumente feitas ao labeling no âmbito da criminologia acabam sendo um reflexo das críticas mais gerais que se faz ao interacionismo simbólico - um rótulo que, como vimos, é criticado por Becker e Goffman - e embora a reflexão sobre essas críticas, no que são ou não procedentes, demandasse um artigo próprio, refutaremos algumas que são mais recorrentes, verdadeiros lugares comuns:

Primeiro convém lembrar que a própria expressão interacionismo simbólico é questionável, e além disso, já vimos que a ideia de que Chicago foi uma escola de pensamento - uma capela - unificada é um mito. Os esquemas e panoramas (incomodamente presentes, por exemplo, em BARATTA, 2002 e SHECAIRA, 2008) que a descrevem como sendo um corpo teórico monolítico, segundo Howard Becker, são equivocados.

Temos, além disso, a acusação de o poder rotulador apareceria como todo poderoso e fatal, e que esta abordagem dos sociólogos formados em Chicago ignora as questões referentes à criminalidade e desigualdade social. Basta uma leitura mais atenta da obra de Becker, para perceber que tais críticas vão parecer mais com uma rotulação inadequada do que com críticas 
realmente procedentes. Por exemplo, ele vai denunciar que "Tratar uma pessoa como se ela" fosse em geral, e não em particular, desviante produz uma profecia auto-realizadora. Ela põe em movimento vários mecanismos que conspiram para moldar a pessoa segundo a imagem que os outros têm dela." (BECKER, 2008, p. 44). Mas ele também vai deixar claro que "É evidente que nem lodos aqueles apanhados em ato desviante e rotulados de desviantes se encaminham de modo inevitável para um desvio maior, como já foi sugerido em minhas observações anteriores. As profecias nem sempre se confirmam, os mecanismos nem sempre funcionam. Que fatores tendam a tornar mais lento ou deter o movimento rumo a um desvio crescente? Em que circunstâncias eles entram em jogo?" (BECKER, 2008, p. 46). Ele vai deixar claro, também que o grau em que um ato será tratado como desviante depende de quem comete, de sua classe social, quem acusa o cometimento, etc. (BECKER, 2008, p. 24-25)

Por fim, criticar a ausência de uma teorização exaustiva sobre a desviação primária, sobre as causas primárias da criminalidade (SHECAIRA, 2008) pode ser uma expectativa um tanto surreal em relação a Chicago, seja porque o modelo do grande intelectual (que cria uma grande teoria) parece ser muito mais um modelo europeu do que estadunidense (mais afeito ao modelo do expert que se dedica a um objeto específico), seja porque Becker nega a pretensão de estabelecer uma teoria do labeling, sobre isso, o próprio Becker: "Tenho dito sempre que a investigação dos rótulos envolvidos na produção do chamado comportamento desviante não é uma teoria. Trata-se de uma observação empírica, a de como esse processo se dá. Aquilo que é uma teoria - nunca comprovada e que em minha opinião nunca será porque simplesmente não é verdade - é a sugestão de que exista uma essência de desvio dentro das pessoas que 'faz com que' elas ajam de maneira 'desviante'." (WERNECK, 2008)

22 “Foucault é conhecido por não citar suas fontes e, inclusive, chegou a comentar a importância do estudo das instituições asilares realizado por Goffman (FOUCAULT, 1984, p. 110111). Pensamos que há mais semelhanças entre 'Manicômios, prisões e conventos' (publicado originalmente em 1961) e 'Vigiar e Punir' (publicado originalmente em 1975) do que se poderia suspeitar à primeira vista. Isso não parece evidente, mas uma leitura atenta de ambos pode indicar pontos de contato, temas, problemas e achados comuns nos dois autores, como tentamos demonstrar. Com isso, não negamos suas diferenças e distâncias, nem as especificidades de cada obra em si mesma. Mas as ressonâncias de um livro no outro nos pareceram bastante notáveis" (BENELLI; COSTA-ROSA, 2003).

23 "Desaparecida a lepra, apagado (ou quase) o leproso da memória, essas estruturas permanecerão. Frequentemente nos mesmos locais, os jogos da exclusão serão retomados, estranhamente semelhantes aos primeiros, dois ou três séculos mais tarde. Pobres, vagabundos, presidiários e 'cabeças alienadas' assumirão o papel abandonado pelo lazarento, e veremos que salvação se espera dessa exclusão, para eles e para os que os excluem." (FOUCAULT, 2010c, p. 6-7)

$24 \mathrm{E}$, ainda em diálogo com Foucault, diríamos que a comunidade se reconheceria na loucura da Benfazeja: "Na realidade, uma sociedade se exprime positivamente nas doenças mentais que manifestam seus membros; e isto, qualquer que seja o status que ela dá a estas formas mórbidas: que os coloca no centro de sua vida religiosa como é freqüentemente o caso dos primitivos, ou que procura expatriá-los situando-os no exterior da vida social, como faz nossa cultura." (FOUCAULT, 1984, p. 74) 
BARATTA, Alessandro. Criminologia crítica e crítica do direito penal. Rio de Janeiro: Revan/ICC, 2002.

BECKER, Howard Saul. Outsiders: estudos de sociologia do desvio. Rio de Janeiro: Zahar, 2008.

. The Chicago School, So-Called. Qualitative Sociology. 22 (1), 1999, p. 3-12. Disponível em <http://home.earthlink.net/ hsbecker/articles/chicago.html>. Acesso em 29/05/2012.

BENELLI, Sílvio José; COSTA-RosA, Abílio da. Geografia do poder em Goffman: vigilância e resistência, dominação e produção de subjetividade no hospital psiquiátrico. Estudos de Psicologia. (Campinas). 2003, vol. 20, n.2, p. 35-49. Disponível em $<h t t p: / / w w w . s c i e l o . b r / s c i e l o . p h p ? p i d=S 0103-166 X 2003000200004 \&$ script=sci_arttext $>$ Acesso em 15/05/2012.

BOURDIEU, Pierre. Razões práticas. Campinas: Papirus. 1996.

BRASIL. Constituição da República Federativa do Brasil. 1988.

ELBERT, Carlos Alberto. Manual básico de criminologia. Buenos Aires: Eudeba, 1998.

FAIRCLOUGH, Norman. Discurso e mudança social. Brasília: Editora Universidade de Brasília, 2001.

FouCAULt, Michel. Doença mental e psicologia. Rio de Janeiro: Tempo Brasileiro, 1984.

. Historia da loucura na Idade Clássica. São Paulo: Perspectiva, 2010c.

Vigiar e punir: nascimento da prisão. Petópolis: vozes, 2010a.

. Os anormais: curso no Collège de France (1974-1975). São paulo: WMF Martins Fontes, 2010b.

GoFFMAN, Erving. Estigma: notas sobre a manipulação da identidade deteriorada. Rio de Janeiro: LTC, 1988.

Manicômios, prisões e conventos. São Paulo: Perspectiva, 2010.

Stigma: notes on the management of spoiled identity. Londres: Penguin Books, 1990.

GonçALVES, Francysco Pablo Feitosa. O direito à educação das pessoas com deficiência: uma abordagem dos processos de inclusão e (des)construção de estigmas. 2011. 198, [77] f. Dissertação (Mestrado) - Universidade Católica de Pernambuco. Mestrado em Ciências Jurídicas, 2011.

GUIMARÃes Rosa, João. A Benfazeja. Primeiras estórias. Rio de Janeiro: Nova Fronteira, 1985.

KoCH, Ingedore Grunfeld Villaça. Argumentação e linguagem. São paulo: Cortez, 2000. 
LE BRETON, David. A sociologia do corpo. Petrópolis: Vozes, 2010.

LOPES, Felipe Tavares Paes. Bourdieu e Goffman: Um ensaio sobre os pontos comuns e as fissuras que unem e separam ambos os autores a partir da perspectiva do primeiro. Estudos e pesquisas em psicologia, ano 9, N. 2, Rio de Janeiro: UERJ, p. 389-407. Disponível em <http://www.revispsi.uerj.br/v9n2/artigos/pdf/v9n2a09.pdf> acesso em 10/01/2011.

MELo, Zélia Maria de. Estigmas: A deterioração da identidade social. Seminário Internacional Sobre Sociedade Inclusiva. Belo Horizonte. Anais do Seminário Internacional Sobre Sociedade Inclusiva, 1999.

NoguelRA, Maria Alice Nogueira; CATANI, Afrânio. (Orgs.) Pierre Bourdieu: escritos em educação. Petrópolis: Vozes, 1998.

REUTER, Yves. A análise da narrativa: o texto, a ficção e a narração. Rio de janeiro: DIFEL, 2002.

RoLIM, Marina Ambrozio Galindo. "Sob o sórdido desarrumo": a feiúra em "A Benfazeja"121 f. Dissertação (Mestrado) - Universidade Estadual de Londrina, Mestrado em Letras, 2010.

SASSAKI, Romeu Kazumi. Como chamar as pessoas que têm deficiência? Revista da Sociedade Brasileira de Ostomizados, ano I, n. 1, $1^{\circ}$ sem. 2003, p.8-11. Disponível em $<$ http://www.planetaeducacao.com.br/portal/artigo.asp?artigo=1855>. Acesso em 01/03/2012.

SANTOS, Juarez Cirino. A criminologia crítica e a reforma da legislação penal. Disponível em

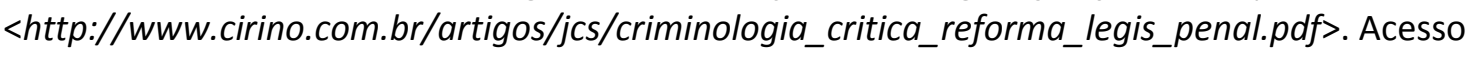
em 28/05/2012.

SHECAIRA, Sérgio Salomão. Criminologia. São Paulo: RT, 2008.

WERNECK, Alexandre. Segredos e truques do pesquisador outsider: Entrevista com Howard S. Becker. Dilemas. vol. 1 - n. 1 - jul-ago-set - 2008. Disponível em $<$ <ttp://revistadil.dominiotemporario.com/doc/Dilemas1Ent.pdf> Acesso em 29/05/20012.

ZAFFARONI, Eugenio Raúl. Tratado de derecho penal: parte general - tomo I. Buenos Aires: EDIAR, 1998.

\section{Para citar este artigo}

GONÇALVES, F. P. F. Os estigmas da benfazeja: mediando um diálogo entre Guimarães e Goffman. Macabéa - Revista Eletrônica do Netlli, Crato, v. 1., n. 1., 2012, p. 0332 . 
Francysco Pablo Feitosa Gonçalves é Bacharel em Direito pela Universidade Regional do Cariri - URCA, Especialista em Direito da Administração Municipal pela Faculdade de Juazeiro do Norte - FJN, Especialista em Sociologia e História pela Universidade Regional do Cariri - URCA e Mestre em Direito pela Universidade Católica de Pernambuco - UNICAP (bolsista CAPES/PROSUP). Atuou como Professor Colaborador na Universidade Regional do Cariri - URCA, nos cursos de formação de professores (Licenciatura Plena para Docência no Ensino Médio com Habilitação em Áreas Específicas) e nos Cursos de Especialização em Língua Portuguesa e Arte/Educação. Atualmente é pesquisador do Grupo de Pesquisa Direitos Fundamentais: Instrumentos de concretização (UNICAP), Professor da Faculdade Estácio do Recife (Estácio - FIR, outrora denominada Faculdade Integrada de Recife) e Professor da Faculdade Integrada de Pernambuco - FACIPE. É ainda Advogado (licenciado). Tem manifestado interesse pelas questões referentes aos direitos humanos, na perspectiva de sua justiciabilidade (nacional e internacional) e no que se refere à reivindicação/afirmação dos direitos dos grupos vulneráveis e sua organização em movimentos sociais. Para além das questões jurídicas, tem interesse em outras áreas, tais como Filosofia, Sociologia, Letras e Pedagogia, bem como nas suas interfaces com o Direito. 